\title{
Assessing the dynamic tourism inter-industry linkages and economic structural changes in Cambodia's economy
}

\author{
Chantha Hor ${ }^{*}$ (1)
}

\section{*Correspondence:}

hor.chantha@a.mbox.

nagoya-u.ac.jp

Graduate School

of International

Development,

Nagoya University,

Furo-Cho, Chikusa-Ku,

Nagoya 464-8601, Japan

\begin{abstract}
This study employs the SAM-based model combining with multiplier product matrix and field of influence approaches. Under three input-output transaction table matrices of the years 2005, 2010, and 2015, these approaches assess the dynamic tourism inter-industry linkages and structural economic changes in Cambodia. We find that the overall inter-industry connection is relatively low. The textile, other manufacturing, and transportation and communication are key sectors. They have the largest coefficient field of influence of changes in the economic system. Tourism has shifted to be a key sector in 2010 and 2015. However, its backward and forward linkages are still small. It is a relatively promising sector generating a large coefficient field of influence of changes, showing less strength of overall connection with other industries. This study may suggest that there would be a need for promoting, encouraging, and investing in key economic sectors. Policy intervention should focus on developing domestic tourism linkages and strengthening inter-industry ties to diversity tourism benefits the local economy.
\end{abstract}

Keywords: Tourism inter-industry linkage, Structural changes, SAM-based inputoutput model, Multiplier production matrix model, Field of influence

JEL Classification: L16, R15, Z32

\section{Introduction}

Tourism has endorsed an economic powerhouse contributing to economic development. Globally, it shared $10 \%$ of gross domestic product (GDP), $29 \%$ of service exports and created a job in every ten jobs in 2018 (UNWTO 2018).

Interestingly, it has been primarily recognized as a leading economic facilitator in either developed or developing countries. In 2018, the travel and tourism industry internationally ranked the second-swiftest flourishing sector. It accounted 3.9\% annual average growth rate, marginally behind the manufacturing industry (4\%) (WTTC 2019). The ongoing expansion of tourism development has brought many scholars to identify its role in the economic system. Furthermore, many governments in developing countries place the tourism sector into their country's priority economic development plan. As is well recognized, tourism is a notable multi-sectorial and inseparable sector, being

(c) The Author(s), 2021. Open Access This article is licensed under a Creative Commons Attribution 4.0 International License, which permits use, sharing, adaptation, distribution and reproduction in any medium or format, as long as you give appropriate credit to the original author(s) and the source, provide a link to the Creative Commons licence, and indicate if changes were made. The images or other third party material in this article are included in the article's Creative Commons licence, unless indicated otherwise in a credit line to the material. If material is not included in the article's Creative Commons licence and your intended use is not permitted by statutory regulation or exceeds the permitted use, you will need to obtain permission directly from the copyright holder. To view a copy of this licence, visit http:// creativecommons.org/licenses/by/4.0/. 
integrated by various activities (e.g., travel, accommodation, art and entertainment, and other service activities) and does not appear as a specific sector in either the input-output table (IOT) or national account system (Fletcher 1989; Teigeiro and Díaz 2014). Hence, many studies use different ways to define this sector, especially in the context of rich and poor data availability and data compilation in the national account system or IOT for the tourism economic impact and linkage estimations. For example, some scholars have defined the tourism sector by using the closet tourism-related characteristic or tourism-related industry (see Pambudi et al. 2009; Pratt 2011; Chaivichayachat 2017; Kronenberg et al. 2018). Lately, some papers have integrated the tourism satellite account (TSA) into the framework of the IOT to examine the tourism economic impact (Madsen and Zhang 2010; Jones and Munday 2010; Munjal 2013; Smeral 2015). Cambodia has seen a limitation of tourism data compared to its neighboring countries. In this context, this study terms the tourism sector by aggregating three of the most closet tourism-related sectors in Cambodian IOT: (33) accommodation and food services; (34) art, entertainment, recreation, and other service activities; (35) other service activities (travel agency, tour operator, reservation service, and other activities). Conspicuously, tourism has articulated with many industries in the IOT, which records the business transaction of all economic activities in the economy (Zha et al. 2019). It generates economic benefits via the intra- and inter-sectorial links between the tourism-related and other sectors (Grosso et al. 2007). In past studies, scholars have applied several economic impact tools ${ }^{1}$ to understand the tourism economic impact and its linkages at different levels (local, national, regional, and global) (see Archer and Fletcher 1996; Dwyer et al. 2003; Kweka et al. 2003; Pambudi et al. 2009; Pratt 2011; Khanal et al. 2014; Teigeiro and Diaz 2014; Antara and Sumarniasih 2017; Kronenberg et al. 2018; Ferrari et al. 2018; Zha et al. 2019). Although there are likely abundant studies in tourism economic impact, there has remained a lack of studies using multiple periods of IOT in developing countries. Furthermore, there have also been inadequate tools to explain the tourism industry's linkage pattern in developing countries.

This paper, to fill the shortage, provides empirical research for the case of Cambodia. Cambodia is a less developed country in Southeast Asia, which borders to the northwest with Thailand, to the north with Lao PDR, and to the east with Vietnam. Cambodia's economy has approximately grown by about 7.7\% from 1995 to 2018, annually (ADB 2019). The government accounted for the tourism sector as an essential economic activity and gave equal weight to the agriculture and manufacturing industry (Kaynak and Kara 2012). Importantly, it has been integrated into the top country's priority strategic development plan for achieving economic development and poverty alleviation (ROG 2018). Nevertheless, most studies have overlooked this industry. Meanwhile, many papers have focused on the garment and textile (Yamagata 2006; Asuyama and Neou 2012), the agriculture and fishery (Kobayashi et al. 2009), and agriculture and agro-agriculture industry (Chhuor 2017).

To this end, this paper structures to assess the dynamic tourism inter-industry linkages and economic structural changes in Cambodia's economy. I use 3 years of the IOT

\footnotetext{
${ }^{1}$ Input-output (IO) model, social accounting matrix (SAM) model, computable general equilibrium (CGE) model, Tourism satellite account (TSA) model.
} 
(2005, 2010, and 2015). This study aims to address two central questions: How does the economic structural change evolve in a nationwide economy? How does the tourism industry important in the Cambodian economy in terms of linkages? This research makes three contributions. First, it enriches discussion on how to integrate government policy intervention to adjust domestic production to satisfy the future tourism demand. Second, it enhances debates about the evolution of tourism linkage's pattern in the economy. Third, it is the first study to perform the field of influence approach for an in-depth illustration of how the tourism industry interconnects with other sectors.

This study designs into seven sections. Sections 2 and 3 outline tourism development in Cambodia and relevant previous studies, respectively. Then, Sects. 4 and 5 describe the research method and data source. Section 6 interprets the result and discussion, and finally, Sect. 7 is the conclusion.

\section{Tourism development in Cambodia}

Cambodia's tourism sector has been reinstated to play a predominant role in the economy in 1992 after a period of disappearance. This absence was because of the civil war, armed conflicts, and political instabilities in the 1970s and 1980s (Chheang 2009). Cambodia has many excellent tourism endowments, such as archeological heritage, historical, cultural, and natural resources (ADB 2009). These tourism endowments are located in various geographical areas of the country. These endowments can attract millions of tourists to visit Cambodia (Kaynak and Kara 2012). In the current decade, an increasing number of inbound tourists in Cambodia registered over time, except in 1997, 2003, and 2009. This exception period of interrupting tourists' inflow hit by the Asian financial crisis, global financial crisis, and other adverse shocks (i.e., SARS epidemics and political instability) (Hor and Thaiprasert 2014). The inbound tourists in Cambodia have surprisingly soared from 60,000 in 1991 to 6.2 million in 2018 (as seen in Fig. 1). Similarly, the tourism receipts remarkably raised from US\$ 100 million in 1995 to US\$ 4.4 billion in 2018 (MOT 2019). Comparing with other ASEAN countries, Cambodia has achieved the highest growth share of tourism GDP (2000-2018), tourism employment (20042018), and tourism visitor's export (2005-2018) (WTTC 2019).

Perhaps, because of its continued growth and expansion, the Cambodian government has integrated the tourism sector into the top national development plan for "growth, employment, equity, efficiency, and poverty alleviation" (ROG 2018). It appeared in the 5-year national socio-economic development plan (NSEDP) (1995-2000), the national strategic development plan (NSDP) (2001-2005, 2006-2010, and 2014-2018). The government has identified various barriers to tourism development (i.e., high cost of the package tour, inadequate physical infrastructure, low tourism service quality, shortage of human resource quality, lack of tourism products, and external adverse shocks). The plan has proposed various action plans, i.e., improving physical infrastructures, opening sky policy, diversifying tourism products and services, visa facilitation, tourism promotion campaign, and developing tourism products at priority tourism areas (Northwest Zone, Central Zone, Coastal Zone, and Eco-tourism Zone). Besides, the government 


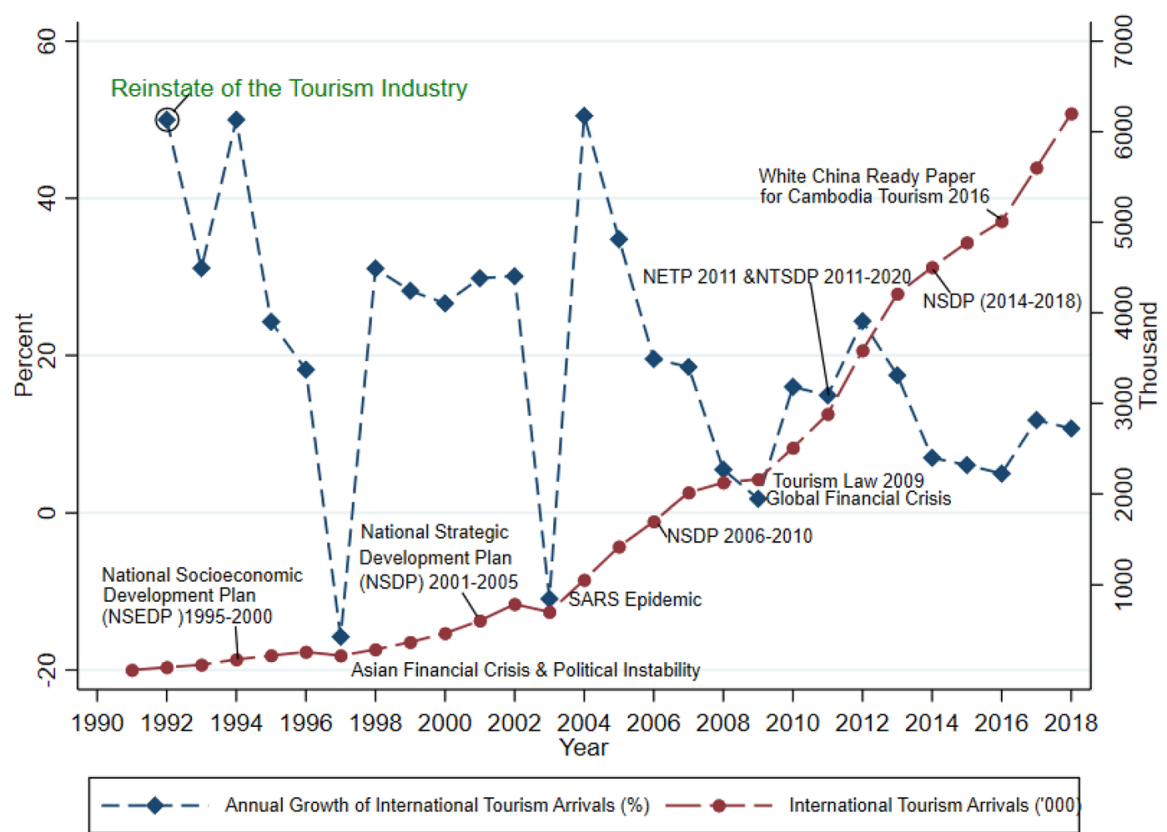

Note: National ecotourism development policy (NETP), National tourism strategic development plan (NTSDP)

Fig. 1 International tourism development in Cambodia, 1991-2018 National ecotourism development policy (NETP), National tourism strategic development plan (NTSDP) (source: author's elaboration based on World Development Indicators (2021), MOT (2012), and ROG (2018))

issued tourism law and strategic development plans $^{2}$ to develop, promote, diversify tourism destinations and enhance local economic benefits. In addition, the Ministry of Tourism of Cambodia issued the "White Paper on China Ready for Cambodia's Tourism" policy in 2016 to attract two million Chinese tourists per year. This policy supports Chinese signage and visa processing documents, promotes Chinese Yuan currency and language, employs Chinese speakers, prepares tourism documents in Chinese, and accredited tourism sites as China-ready by ensuring that foods and accommodation facilities satisfy Chinese taste. Undeniably, the tourism sector has been considered by the government to boost Cambodian economic development. However, as reported by the Cambodian Ministry of Tourism, the tourism sector relatively small contributes to the domestic economy due to the considerable size of economic leakage.

\section{Literature review}

The linkage analysis is predominant in understanding the inter-industry association between sectors in the economy. It equips a few essential advantages. First, it gives an overall picture of economic structure and how domestic production has changed overtimes. Second, it accommodates information for the sector's classification or

\footnotetext{
$\overline{2}$ Tourism law in 2009, national tourism strategic development plan (NTSDP) (2011-2020), national ecotourism development plan (NETDP) in 2011.
} 
industry's position in the economy. Third, it shows the strength of linkages among industries (Pratt et al. 2018; Gabriel and Ribeiro 2019). There are two types of economic linkages, i.e., backward linkage (BL) and forward linkage (FL) (Cai et al. 2006). The BL reveals demand relation between sectors. For example, if industry (A) enlarges producing its products, there is then bourgeoned demand on other industries whose outputs utilize raw materials in the sector (A). The FL marks the supply association. It makes up an increase in producing products in the industry (B) is the additional volume in production at sector (B) is available to be used as raw materials/intermediate goods for another industry's output.

The linkage analysis tools, over the last six decades, have been adopted for economic development studies to convey the interdependence and inter-sectoral linkages between industries. Evolutionally, the linkage methods were firstly introduced by Rasmussen (1956), Hirschman (1958), and Chenery and Watanabe (1958). Later, there have been extensively developed and broadly discussed (see Schultz 1977; Celia 1984; Sonis et al. 1997; Miller and Blair 2009; Temurshoev 2010).

A plethora of studies use various econometric tools to investigate the tourism economic impact and its linkages in different countries. Previous studies have been done for the case of Lao PDR (Khanal et al. 2014), Malaysia (Mazumder et al. 2011), China (Oosterhaven and Fan 2006), India (Munjal 2013), Indonesia (Antara and Sumarniasih 2017), Thailand (Vora-Sittha 2016), Turkey (Akkemik 2012), Central Finland (Tohmo 2018), Ireland (Henry and Deane 1997), South Korea (Kim and Kim 2015), and Israel (Freeman and Sultan 1997). Henry and Deane (1997) use the IO approach to calculate the effects of tourism expenditure and passenger fares on Ireland's economy between 1990 and 1995. The study finds that the tourism sector contributes to Ireland's output between 7 and 11 percent. Atan and Arslanturk (2012) exert the IO model to study tourism and economic growth nexus, including exploring tourism economic linkages in Turkey. The finding shows that tourism is not a vital sector in Turkey. Furthermore, all tourism-related industries have a high value of backward linkages.

Yousif and Al Bakr (2017) utilize the IO approach to evaluate the role of tourism on Saudi Arabian economic diversification. Their finding indicated that tourism has a positive direct-and-indirect impact on Saudi Arabian economy. The scholars suggest increasing budgets on the tourism industry to diversify the country's economy to achieve the country's vision 2030. Khanal et al. (2014) use a series of linkage methods to evaluate the inter-industry linkage between Lao PDR tourism and other industries based on the IOT 2003-2008. The study found that the Lao PDR tourism industry contributes positively to the level of dependency in the economy during 2003-2008. Manufacturing, agriculture, wholesale and retail, food and beverage, and tourism sector are the dominant sector over the studied periods. The enlargement of the tourism industry stimulates and enables the country to be one of the highest economic growth in the Great Mekong sub-region countries. Chaivichayachat (2017) examines the inter-sectorial linkage between related-tourism sectors in Thailand by separating three main periods, such as in the past (1975-2013), in the present (2014-2016), and the future (2017-2027). He finds the tourism-related industry is backward-oriented in the past and moves to the forward-oriented sector in the present and future periods. The fast-growing pace of the tourism sector starts more significant linkages on 
the country's economy than in the past. His study also suggests numerous policies to promote tourism and enhance the Thai economy.

Akkemik (2012) explored the SAM approach to estimate the economic contribution of the tourism industry to Turke's economy. The result shows that tourism GDP elasticity is relatively tiny. Tourism expenditures are a medium impact on production, value-added, and employment. The study also emphasized that there was a high probability of foreign economic leakages in the Turkish economy. A similar study was done by Muchapondwa and Stage (2013) for the case of South African, Motswana, and Namibian economies. The outcome demonstrates tourism's overall economic impact on South African GDP, about 6 percent, and 9 percent for Namibia. The study pinpoints that the economic leakage in South Africa is smaller than its neighboring countries. Although there are abundant tourism studies exploring tourism linkages and their economic impact, few studies concern the tourism industry's dynamic and evolutionary linkage pattern. Furthermore, those studies have overlooked the direct change coefficient of inter-industry with the other sectors using the Field of Influence approach.

\section{Research method}

The SAM-based input-output model is used in this study, followed by Defourny and Thorbecke (1984) and Otchia (2013, p. 92):

$$
\mathbf{y}=(\mathbf{I}-\mathbf{A})^{-1} \mathbf{x}=\mathbf{B x},
$$

where $\mathbf{y}$ and $\mathbf{x}$ are the receipts from income and expenditure accounts, respectively; $\mathbf{A}=$ $\left[a_{i j}\right]$ is an input coefficient matrix; $\mathbf{B}=(\mathbf{I}-\mathbf{A})^{-1}$ is the Leontief inverse matrix. The income account composes activities, commodities, households, and factors of production account, while capital, government, and the rest of the economy are assigned to be expenditure accounts.

Following Otchia (2013, p. 92-93), I use the minimum information method to decompose the matrix of Leontief inverse (MLI) into two components, namely the multiplier product matrix (MPM) and the matrix synergetic interaction (MSI). Therefore, the minimum information depended on the decompose MLI, which can express Eqs. (2) and (3) as:

$$
\begin{aligned}
& \mathbf{B}=\mathbf{M}-\mathbf{N}, \\
& \mathbf{B}=\mathbf{M}+\mathbf{D}+\mathbf{S}+\mathbf{S}_{\mathbf{a}},
\end{aligned}
$$

where $\mathbf{M}$ and $\mathbf{N}$ are the MPM and MSI matrix, respectively, $\mathbf{D}$ refers to the additional sectorial scale effects. $\mathbf{S}$ and $\mathbf{S}_{\mathbf{a}}$ are the symmetric and anti-symmetric tendencies in the synergetic cooperation between industries.

\subsection{Key sector analysis}

Following Otchia (2013, p. 93), the MPM approach is employed to illustrate how a sector is associated with other sectors in the economy and presents the intensity of this connection. This approach is equated as below: 


$$
\mathbf{M}=\frac{1}{v}\left[\mathbf{B}_{\mathbf{i} .} \mathbf{B}_{\mathbf{j} .}\right]=\frac{1}{v}\left[\begin{array}{c}
\mathbf{B}_{\mathbf{1}} \\
\mathbf{B}_{2 .} \\
\vdots \\
\mathbf{B}_{\mathbf{n} .}
\end{array}\right]\left[\mathbf{B}_{.1} \mathbf{B}_{.2} \cdots \mathbf{B}_{. \mathbf{n}}\right]
$$

where $v=\sum_{i=1}^{n} \sum_{j=1}^{n} b_{i j}$ is a summation of all cells in the inverse matrix; $\mathbf{B}_{\mathbf{i}}=\sum_{i=1}^{n} b_{i j}$ and $\mathbf{B}_{\mathbf{j}}=\sum_{i=1}^{n} b_{i j}$ is the summation of the total $i$ th row and $j$ th column of MLI, respectively.Sonis et al. (2000) and Otchia (2013, p. 93-94) describe that the MPM's structure is associated with the sectorial backward and forward linkages. These authors indicate that the row and column multipliers for MPM are the same as those for the Leontief inverse matrix. Therefore, the key sector analysis based on Rasmussen-Hirschman linkages indices can be performed within the MPM.

The Rasmussen-Hirschman backward $\left(\mathbf{B L}_{\mathbf{j}}\right)$ and $\left(\mathbf{F L}_{\mathbf{i}}\right)$ linkages can be equated as followed (Otchia 2013, p. 94):

$$
\begin{aligned}
& \mathbf{B L}_{\mathbf{j}}=\frac{\frac{1}{n} \sum_{i=1}^{n} b_{i j}}{\frac{1}{n^{2}} \sum_{i . j=1}^{n} b_{i j}}=\frac{\frac{1}{n} \mathbf{B}_{\mathbf{j}}}{\frac{1}{n^{2}} v}=\frac{\mathbf{B}_{\mathbf{j}}}{\frac{1}{n} v}, \\
& \mathbf{F L}_{\mathbf{i}}=\frac{\frac{1}{n} \sum_{j=1}^{n} b_{i j}}{\frac{1}{n^{2}} \sum_{i, j=1}^{n} b_{i j}}=\frac{\frac{1}{n} \mathbf{B}_{\mathbf{i} .}}{\frac{1}{n^{2}} v}=\frac{\mathbf{B}_{\mathbf{i}}}{\frac{1}{n} v},
\end{aligned}
$$

where $\mathbf{F L}_{\mathbf{i}}$ and $\mathbf{B} \mathbf{L}_{\mathbf{j}}$ represent the index of forward and backward, respectively. $n$ is the number of sectors. I conclude four types of industries: (i) key sectors (both linkages measure larger than 1); (ii) backward-oriented sectors (only, $\mathbf{B L}_{\mathbf{j}}>1$ ); (iii) forward-oriented sectors (only, $\mathbf{F L}_{\mathbf{i}}>1$ ); and (vi) weak sectors (both linkages measure smaller than 1).

In addition to the linkage analysis, I can establish the structural landscape of the economy by reorganizing the structure of MPM (Otchia 2013). The summation of the $i$ th row and $j$ th column of the MPM is restructured based on the rank-size hierarchy of the FL and BL. The components of the MPM in this hierarchical system show the strength of the first order of field of influence of changes. These strengths are utilized to estimate crucial inverse parameters for which changes create the most extensive effects in the IO system (Otchia 2013, p. 94).

\subsection{Matrix of impacts of synergetic interactions (MISI)}

The matrix of impacts of synergetic interactions (N) expresses as Eq. (7) for interpreting the changes of two components of the direct input matrix. Then, the MISI has broken down into escalating impacts of the inter-industry production activities $(\mathbf{D})$ and linkages (R) as Eqs. (8) and (9):

$$
\begin{aligned}
& \mathbf{N}=\mathbf{M}-\mathbf{B}, \\
& \mathbf{D}=\operatorname{diag}(\mathbf{B}-\mathbf{M}), \\
& \mathbf{R}=\mathbf{B}-\mathbf{M}-\mathbf{D},
\end{aligned}
$$


where $\mathbf{D}$ and $\mathbf{R}$ are the matrices of diagonal $\mathbf{N}$ and residual with a zero main diagonal. The last decomposition of the MISI is that $\mathbf{R}$ has to divide into two components, symmetric (S) and anti-symmetric $\left(\mathbf{S}_{\mathbf{a}}\right)$. According to Otchia (2013, p. 95), these two components show the respective balance and unequal between industrial inputs and outputs. I can express it as Eq. (10):

$$
\mathbf{R}=\frac{1}{2}\left(\mathbf{R}+\mathbf{R}^{\mathrm{T}}\right)+\frac{1}{2}\left(\mathbf{R}-\mathbf{R}^{\mathrm{T}}\right)=\mathbf{S}+\mathbf{S}_{\mathbf{a}}
$$

where $\mathbf{R}^{\mathrm{T}}$ is the transposed matrix.

\subsection{Direction of change in the Leontief inverse}

In addition to linkage and economic landscape analysis, I apply the field of influence approach to evaluate the direction of change in the matrix of Leontief inverse, which is heavily adopted the equations from the Otchia (2019). It helps to measure the changes of direct input coefficients and their linkage impacts on the component in the MLI. The changes in the linear input coefficient can express as the following equation:

$$
\Delta a_{i j}=a_{i j}(t+1)-a_{i j}(t)
$$

where $\Delta a_{i j}$ is the change of linear input coefficient at period $t$ and $t+1 ; a_{i j}(t)$ is the coefficient of direct input at time $t$.

I control the changes of direct input coefficient at time $t$ and $t+1$; parameter $0 \leq \varepsilon \leq 1$ introduces as the following equation:

$$
a_{i j}(\varepsilon)=a_{i j}(t)+\varepsilon \Delta a_{i j} .
$$

The matrix $\mathbf{A}(\varepsilon)=\left[a_{i j}(\varepsilon)\right]$ and its corresponding Leontief inverse $\mathbf{M}(\varepsilon)=\left[a_{i j}(\varepsilon)\right]^{-1}$ are considered as follows:

- The $\varepsilon=0, \mathbf{A}(0)$ presents the technical coefficient matrix at period $t$ with the Leontief inverse, $\mathbf{A}(0)^{-1}$;

- The $\varepsilon=0, \mathbf{A}(1)$ marks the technical coefficient matrix at time $t+1$ with the inverse Leontief, $\mathbf{A}(1)^{-1}$;

- For the small values of $\varepsilon$, the expression $\mathbf{H}(t+1, t)=\frac{[M(\varepsilon)-M(0)]}{\varepsilon}$ is nearly constant, and the number of directions of changes in the Leontief inverse from period $(t)$ and $(t+1)$.

\section{Data}

Cambodian IOT has been developed and released by the researcher and international institutions. Dr. OUM Sothea established the first IOT. His 2 years of IOT (2004 and 2008) have officially been published in the Global Trade Analysis Project (GTAP) database. It composes $35 \times 35$ sectors for the year 2004 and $22 \times 22$ industries for the year 2008. The second source is the $60 \times 60$ Supply and Use Table 2011, developed by ADB (2012). The third source of IOT has established by the Organisation for Economic Cooperation and Development (OECD). It contains $35 \times 35$ sectors covering from 1995 to 2015. The OECD constructs the Cambodian IOT, which adopts the industry by industry 
approach. Hence, this table is a handful of structural and linkage analyses because it covers all industries in the economy.

As mention above, this study investigates the dynamic tourism inter-industry linkages and structural economic changes in Cambodia. I choose IOT obtained from the OECD statistical database (https://stats.oecd.org/Index.aspx?DataSetCode=IOTSI4_2018) because it covers a more extended period than other sources. Three years of IOT (2005, 2010, and 2015) have been used in this study. Each original 35-sector IOT is aggregated into 15-sector as Table 1 in Appendix.

\section{Results and discussion}

\subsection{The summary statistics of Cambodian industrial structure, 2005-2015}

This section describes the industrial structure base on IOT of the years 2005, 2010, and 2015, as presented in Table 2. Cambodia's economy depended on the agriculture sector, which accounted for 30\% of total gross output in 2005 and then fell to $29 \%$ in 2015. It was the highest contributor to overall GDP and value-added, but relatively lost its share to the manufacturing and service sectors. During 2005-2015, five economic sectors (namely, food and beverage, transportation and communication, textile, other manufacturing, and tourism sector) were the dominant sector contributing to the total gross output and GDP. These sectors were also the top ranking in terms of providing a significant share to value-added. Meanwhile, all sub-service sectors' stock to gross output and GDP, except tourism, have soared over observed periods. Oppositely, these sectors were nearly constant growth contributing to value-added.

The export and import structure of Cambodia is displayed in Table 3. Cambodia mainly exports agricultural, textile, other manufacturing, and transportation and communication items. These four categories accounted for $84 \%$ of total exports in 2005 and decreased to $79 \%$ in 2015. This trend favored the service sector, which made up $9.7 \%$ in 2005 , and $14 \%$ in 2015 . The tourism sector represented the third-largest share of total exports in the service sector after the wholesale and retail industry. The sector's export intensity is defined as the ratio of each sector's export to domestic production. In 2005, the textile industry was the most export-intense industry, which exported $59 \%$ of its outputs to foreign markets. It is followed by agriculture (46\%), other manufacturing (41\%), and the food and beverage industry (25\%). In 2010, the textile, other manufacturing, and transportation and communication industries showed the top three most export-intense sectors, approximately $49 \%, 43 \%$, and $38.5 \%$, respectively. These industries were ahead of the food and beverage (21\%) and the tourism industry (15.5\%). In 2015, the transportation and communication sector was the second most export-intense, followed by the other manufacturing (37\%), mining and quarry (31\%), agricultural (24\%), and tourism industry $(22.1 \%)$. The export intensity of the tourism sector has surged from $13.1 \%$ in 2005 to $22.1 \%$ in 2015. This increasing trend pinpoints that Cambodia's tourism industry highly depends on the growth of international tourism demand. It is also the main service export, which possibly generates a considerable amount of export-earning. Regarding imports, Cambodia highly imports other manufacturing, textile, wholesale and retail, and transportation and communication items, exhibiting $92 \%$ of total imports in 2005 before decreasing to $85 \%$ in 2015 . The share of tourism import to total import has surged from $0.8 \%$ in 2005 to $5 \%$ in 2015 . As shown in Table 3, the import intensity of the 
tourism sector has surged from $3.5 \%$ in 2005 to $21.2 \%$ in 2015, indicating high economic leakages in this industry. The reasons could be that there was high demand for standard tourism goods and services, increasing the tour packages between Cambodia and its neighboring countries (Thailand and Vietnam), no direct flight between Cambodia and long-haul tourists (Europe and USA), and an increasingly international connecting flight between Cambodia with China and India.

Furthermore, Table 4 shows the structure of labor income and labor intensity of each sector. The agriculture and other manufacturing industry were the highest contributions to total labor income for all 3 years but with a relatively downward trend. Between 2010 and 2015, the top three service sectors (i.e., tourism, wholesale and retail, and transportation and communication) were a significant contributor to the total labor income. These sectors imply the importance of service industries concerning contribution to net value-added. The labor income intensity of each sector is also included in Table 4. It is the fraction of labor income to total domestic production. Two service sectors (public administration and education) were the most labor income-intense industry for all 3 years. It is followed by the tourism industry, which displayed an increasing trend from $27 \%$ in 2005 to $34 \%$ in 2015 . This sector indicates that it potentially generates employment and labor income earning.

\subsection{Backward and forward linkage analysis}

This section illustrates, in Table 5, the result of the Hirschman-Rasmussen BL and FL indices during 2005-2015. The BL is also called the intensity of intermediate inputs. It indicates that a sector demands inputs from other industries for its production. The BL of sector $j$ quantifies the change in economy-wide income relative to the average change in the economy caused by a unitary injection in the final demand of sector $j$. If the BL is more than one, it implies that a unit change in the final demand sector will increase activities in the whole economy (Otchia 2013). The FL shows an economic activity that supplies intermediate inputs to other sectors and final domestic demand. The FL of sector $j$ quantifies the change in income in sector $j$, relative to the average change in the economy, caused by a unitary injection in the final demand of all sectors. If the FL for sector $j$ is more than one, sector $j$ 's income is higher than the average income change in the economy after a unitary injection in all sectors (Otchia 2013). The linkages of each sector have been measured using the PyIO 2.1, a module for IO analysis developed by researchers at the University of Illinois' Regional Economic Applications Laboratory. It is a general-purpose, open-source computer programming language writing in Python.

The analysis finds that 6 out of 15 sectors (namely, food and beverage, other manufacturing, construction, textile, transportation and communication, electricity, and) have relatively had strong backward linkage with the value of greater than one in the threepoint periods. These sectors point out that these industries are input dependent on other economic sectors, showing a significant and positive impact on the nationwide economy. Diversely, the rest of the sectors have shown weak backward linkage. Most service sectors (e.g., wholesale and retail, financial and insurance, real estate, public administration, education, and human health) exhibit low backward linkage. It argues that these industries make relatively less intermediate inputs demand from other economic sectors. The agricultural and mining and quarrying sectors have resulted in a low backward 
linkage, implying that both sectors have a relatively small degree of input dependence on other industries in the economy. The textile, other manufacturing, construction, transportation and communication, and wholesale and retail registered as the top five highest forward linkages across periods. These sectors imply an essential role in supplying inputs to other economic segments. The tourism sector showed a strong forward linkage in 2010 and 2015. The reason could be because of the impact of tourism law and 10-year national tourism strategic development plan (2012-2020) implementation in 2009 and 2011, respectively, that encouraged the private sectors to develop tourism products, increase travel facilitation, develop domestic infrastructure, enhance regional and global connectivity, and diversify tourism destinations. These initiatives lead to an increase in the domestic linkage between tourism and other sectors in the economy. This result is in line with the studies by Beynon et al. (2009), Khanal et al. (2014), and Munjal (2013), who find tourism forward linkage greater than one in the case of the UK's economy, Lao PDR's economy, and India's economy, respectively. In contrast, most service sectors have low forward linkage, exhibiting that these industries are relatively small supply inputs to other economic sectors.

Concerning the linkage trend, the tourism sector has decreased backward linkage overtime periods. This sector pinpoints that this sector is relative to demand intermediate inputs from its sector or sub-related sectors. On the contrary, the tourism sector has increased its forward linkage across times, implying that this sector supplies inputs to other economies via the business travel sector. The strong tourism forward linkage may generate high backward linkage in its related industries. It is in line with the construction, wholesale and retail, and transportation and communication, showing a stable and robust growth of backward linkage. Also, the increasing trend of the forward linkage in both the transport and communication and tourism sectors indicates the importance of these sectors in supplying intermediate inputs to tourism-related sectors and other sectors in the national economy. This finding is consistent with Khanal et al. (2014).

\subsection{Key sector analysis}

The key sector analysis is used to cluster segments into four types: key sectors, forward-oriented sectors, backward-oriented sectors, and weak sectors. This classification is based on normalizing backward-and-forward linkage indices, clearly explained in Sect. 4.1. The observed economic sectors have been categorized into four quadrants, shown in Figs. 2, 3 and 4. The upper right-and-left quadrants are, respectively, key sectors and forward-oriented sectors. The lower right-and-left quadrants are backward-oriented sectors and weak sectors, respectively.

We find that textile, other manufacturing, and transportation and communication sectors are key sectors that have backward and forward linkages higher than one. The tourism sector shifted to a key sector in 2010 and 2015. This sector means that a surging investment or productivity these sectors provide a spillover impact on other industries. The backward-oriented sectors are across 3 years, namely, the food and beverage, electricity, and construction sector. The mining and quarrying sector became a backward-oriented sector in 2015. It indicates that an increase in these sectors' production provides more input demand from other industries. The wholesale and retail sector is continuously a forward-oriented sector across periods. Agriculture became into the 


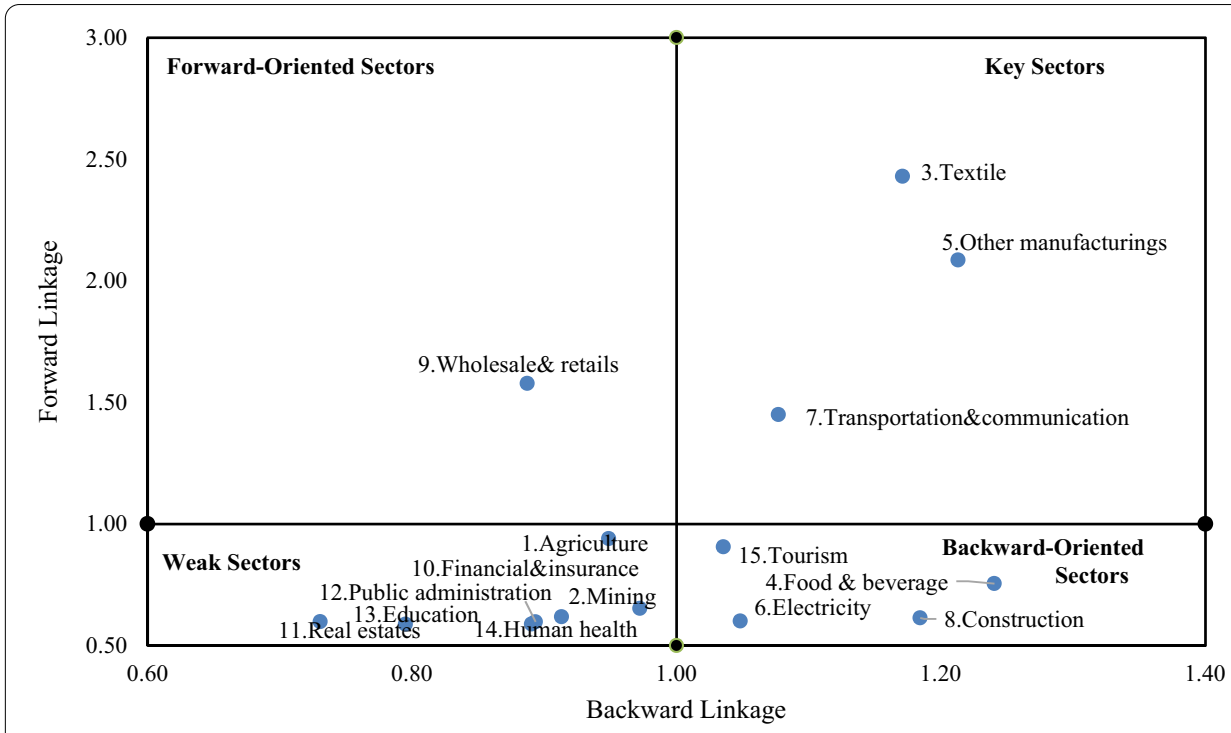

Fig. 2 Key sectors of Cambodia in 2005 (source: author's calculation based on OECD's IO table, 2005)

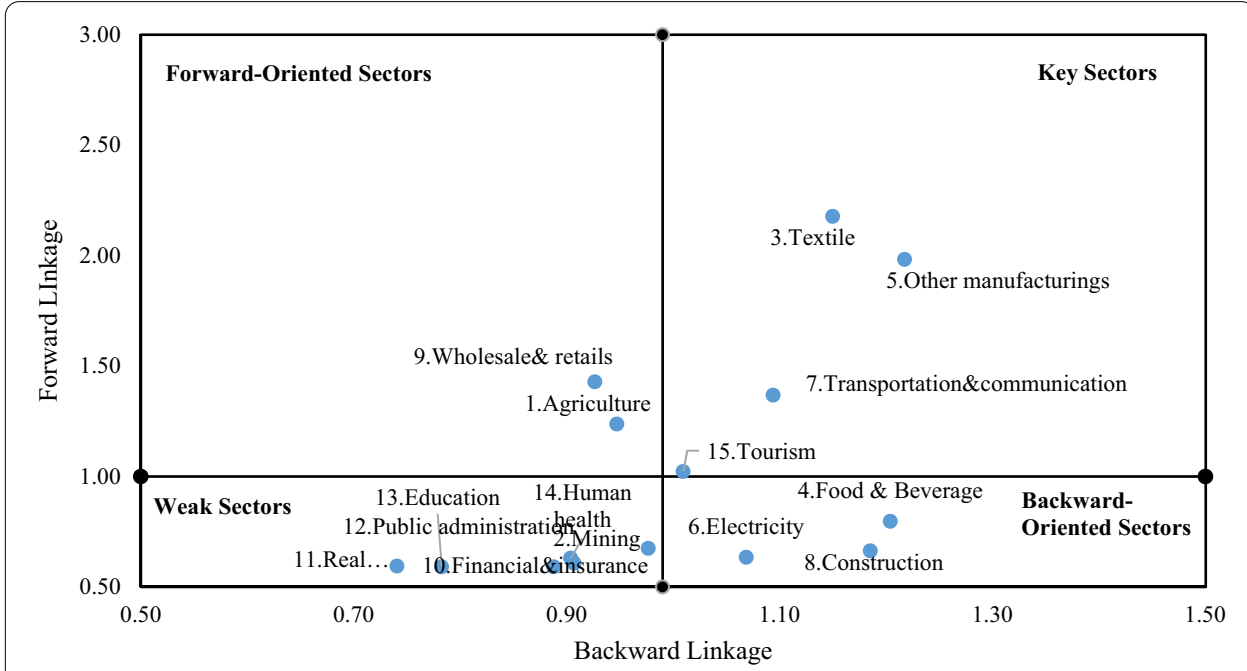

Fig. 3 Key sectors in 2010 (source: author's calculation based on OECD's IO table, 2010)

forward-oriented sectors in 2010 and 2015. This sector implies that these industries' outputs have been used as inputs for other's industrial production. Moreover, there has been seen that most sectors are weak-oriented sectors during the 3 years.

\subsection{The landscape of the Cambodian economy}

Figures 5, 6 and 7 illustrate the Cambodian economic landscape for 3 years $(2005,2010$, and 2015). The graph shows the relationship between structural industries through the hierarchy of forward-and-backward linkage.

In 2005, the landscape economy presented a considerable variation of inter-sectoral linkages, implying a low inter-industry linkage among sectors. The hierarchy of the 


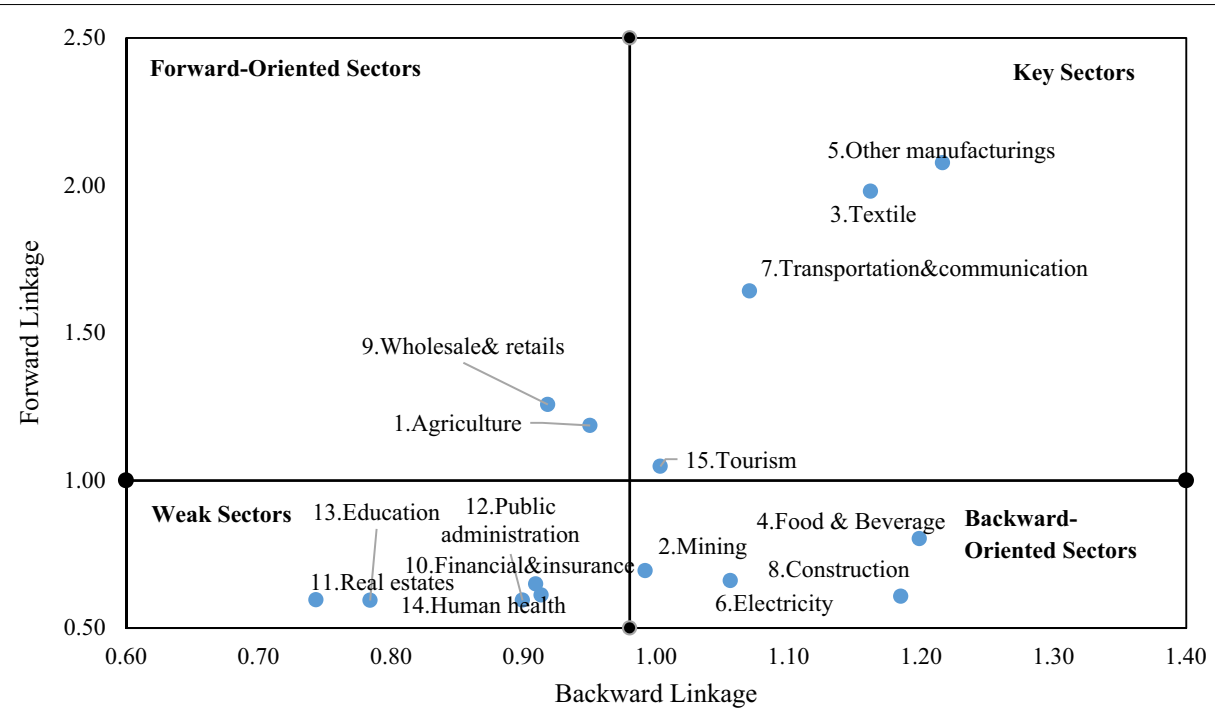

Fig. 4 Key sectors of Cambodia in 2015 (source: author's calculation based on OECD's IO table, 2015

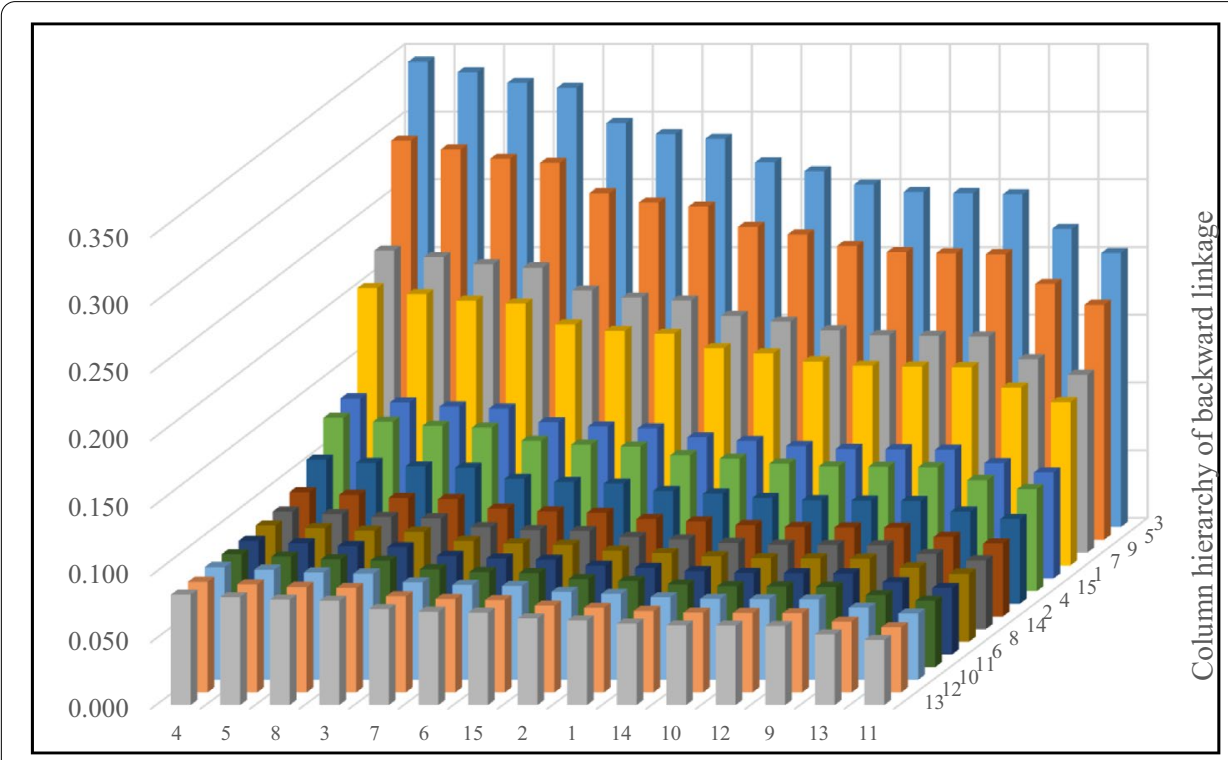

Row hierarchy of forward linkage

Fig. 5 Economic landscape of Cambodian economy in 2005 (source: author's illustration based on OECD's IO table, 2005)

highest bar was the intersection between the food and beverage and textile sector. This conjunction indicates that industrialization played an essential role in Cambodia's economy. The third and four apexes were at the interconnection of economic sectors 8-9 (wholesale and retail-construction) and 3-7 (textile-transportation and communication). This link pinpoints that the manufacturing and service sectors become active in the economy. Also, the sixth and seventh apexes showed the intersection of industries 6-15 (electricity-tourism) and 15-4 (tourism-food and beverage). These sectors have 


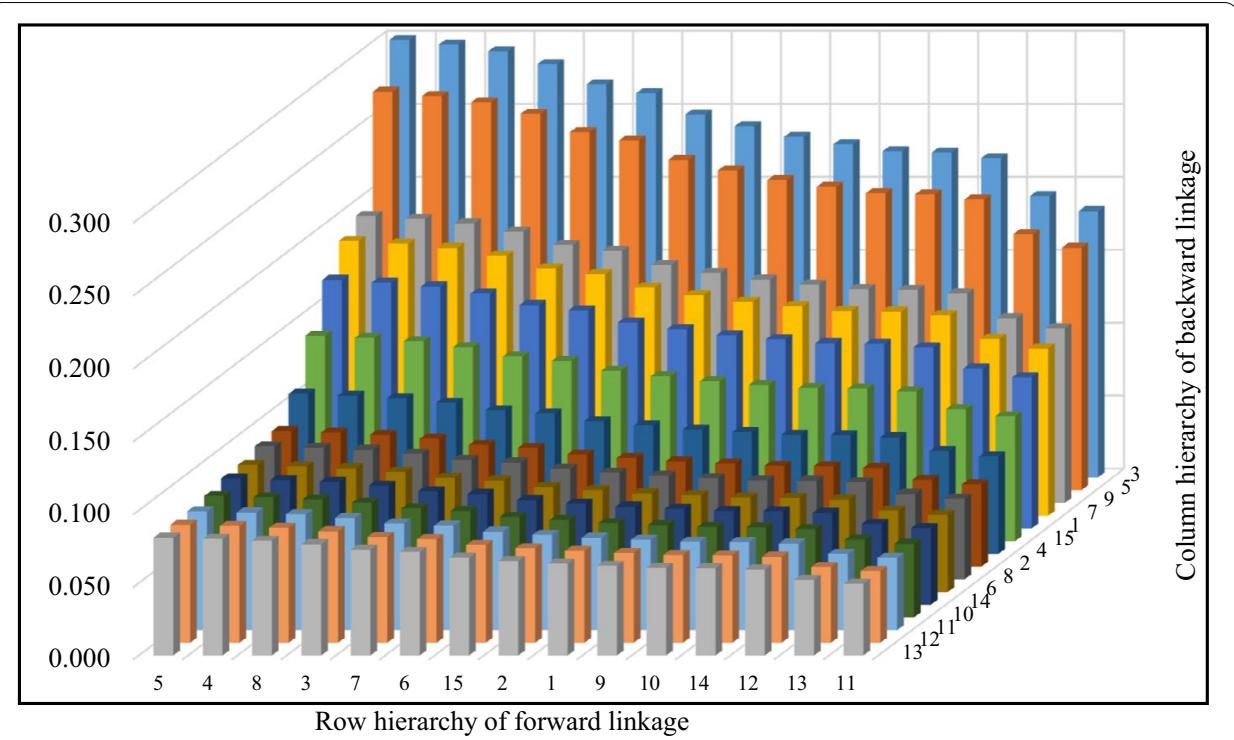

Fig. 6 Economic landscape of Cambodian economy in 2010 (source: author's illustration based on OECD's IO table, 2010)

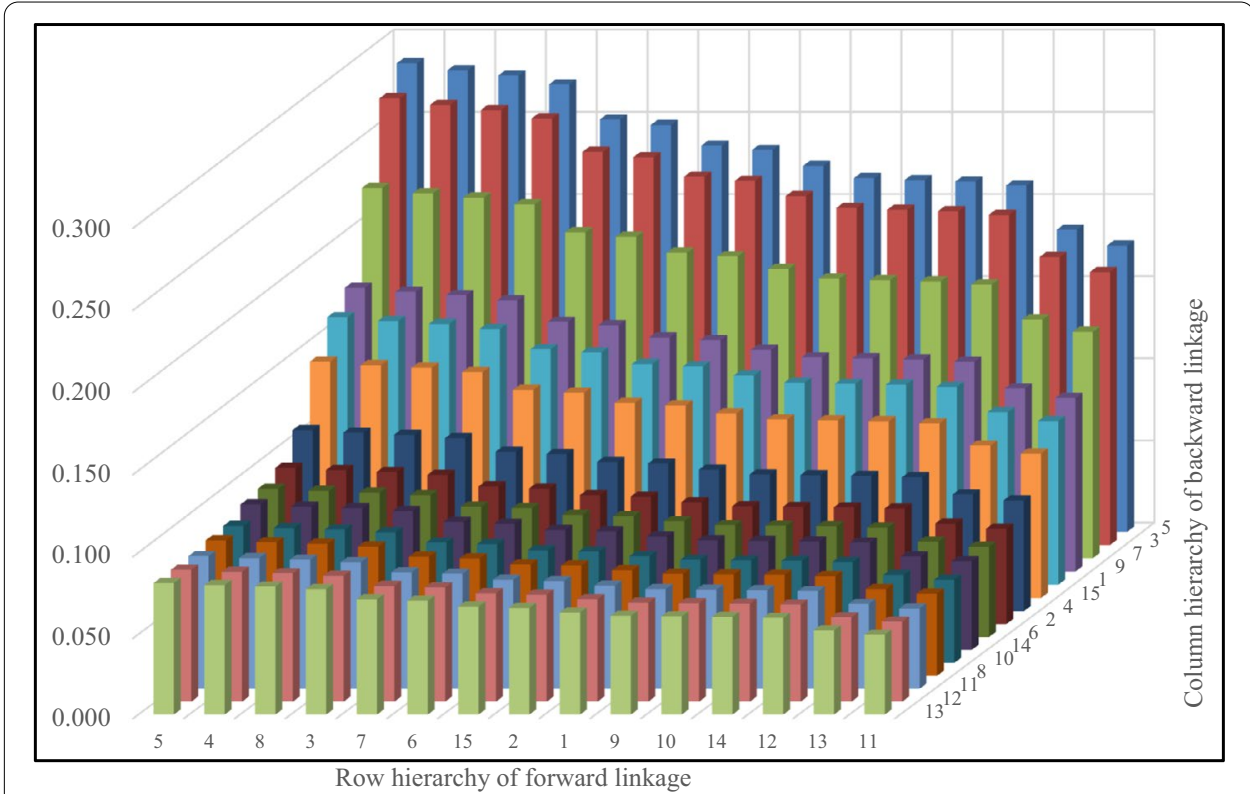

Fig. 7 Economic landscape of Cambodian economy in 2015 (source: author's illustration based on OECD's IO table, 2015)

similar heights, indicating that the tourism, electricity, and food and beverage sectors have a strong inter-link with other industries in the economy.

Figure 6 shows Cambodia's economic landscape in 2010. The highest bar is the junction of sectors 5-3 (other manufacturing-textile), and the second apex is the intersection of industry 4 (food and beverage) and 5 (other manufacture). This linkage reflects that the process of industrialization in Cambodia's economy remains 


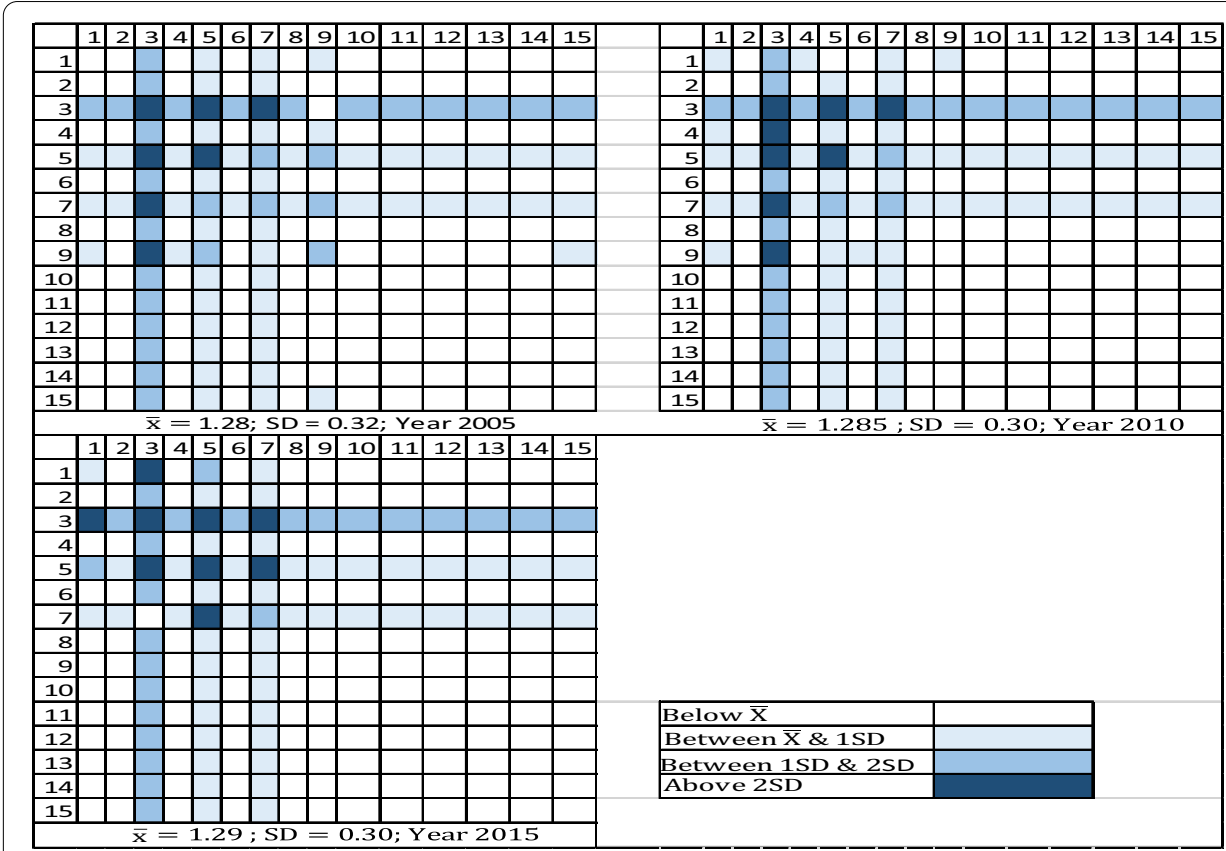

Fig. 8 Field of influence in 2005, 2010, and 2015 for Cambodia (source: author's calculation based on OECD's IO table, 2005, 2010, 2015)

essential for the economic development in Cambodia. The third and four apexes interact with sectors 8-9 (wholesale and retail-construction) and 3-7 (textile-transportation and communication). This interaction presents an active role of sectors in the economy. Also, the sixth and seventh apexes are at the junction of the industry 6-15 (electricity-tourism) and 15-4 (tourism-food and beverage). The height of these sectors has relatively more variation than in 2005, presenting a low association between tourism, electricity, and food and beverage. Thus, there is a shortage of domestic products supplied to the tourism sector when tourism expands. The economic landscape of Cambodia in 2010 shows a considerable variation in interindustry linkages.

Similarly, Fig. 7 exhibits the Cambodia economic landscape in 2015. The highest bar is the junction of sector 5 (other manufacturing) and itself. It is followed by the intersection of industry 4-3 (food and beverage-textile). The third and four apexes are at the inter-link of sectors 8-7 (construction-transportation and communication) and 3-9 (textile-wholesale and retail), followed by the fifth apex of the interindustry linkage between industry 7 (transportation and communication) and sector 1 (agriculture). This interaction indicates that agriculture, other manufacturing, and service sector are actively economic performance in the economy. Also, the association between tourism and other economic sectors did not change in 2015. The economic landscape of Cambodia in 2015 shows a significant variation in inter-industry linkages. 


\subsection{Field of influence}

I use the field of influence approach to further investigate the sectors' interdependences for the years 2005, 2010, and 2015, in addition to the linkage analysis and economic landscape. This approach extends the conventional key sector analysis and economic landscape by defining the combination of key sectors that have the most significant contribution to economy-wide output. According to Otchia (2013), this approach is essential to define sectors where policy intervention will create the most significant volume change in Cambodia's economy. As can be seen in Fig. 8, each productive linkage is highlighted as the color scales. The blank box and lighter colors note the value of coefficients below the mean and above mean plus a standard deviation, respectively - the intermediate color marks between one and two standard deviations. The darker blue color marks the above two standard deviations-the result presented in Fig. 8. Three industries, namely, textile (sector 3), other manufacturing (sector 5), and transportation and communication (sector 7), reveal the most significant coefficient of the field of influence of changes during the 3 years. These sectors present more importance in the economy. At the same time, the rest of the industries have relatively lost the critical coefficient of Field of Influence over the examined periods.

In terms of linkages, the agriculture sector has intensively interconnected (above two standard deviations) with the textile sector in 2015 and intermediated linkage in the rest of the 2 years. The textile industry has integrated into the production process within the industry itself and the most robust strength linkage (above average plus two standard deviations) with other manufacturing, and transportation and communication. Interestingly, the wholesale and retail sector presents the most substantial ties above average plus two standard deviations with the textile sector in 2005 and 2010, but less intensity in 2015. During the three periods, the tourism sector shows the most robust strength linkage (between one to two standard deviations) with textile (sector 3) and between mean to one standard deviation for the other manufacturing (sector 5) and transportation and communication (sector 7). Surprisingly, the tourism sector is relatively lost linkage with the agriculture (sector 1), food and beverage (sector 4), and wholesale and retail (sector 9), indicating weak domestic linkages among these sectors causing high economic leakages through high demand for imported goods.

\section{Conclusion}

This study uses an input-output table of 3 years $(2005,2010$, and 2015) to investigate the dynamic inter-sectorial linkages of the tourism sector and structural economic changes in Cambodia. This paper employs the multiplier product matrix and field of influence approaches.

I find that 7 out of 15 sectors (namely, food and beverage, other manufacturing, construction, textile, transportation and communication, electricity, and tourism) show higher backward linkage during 2005-2015. Sectors, such as textile, other manufacturing, transportation and communication, and wholesale and retail, exhibit the top four strong forward linkages. The tourism sector moved to be the top 5 highest 
forward linkages in 2010 and 2015. Moreover, most service sectors (e.g., wholesale and retail, financial and insurance, real estate, public administration, education, and human health) demonstrate a weak backward linkage.

This study also reveals that the overall inter-industry linkage is relatively low during the observed periods. However, we find textile, other manufacturing, transportation and communication, and tourism as four potential key sectors. More interestingly, except for the tourism sector, these sectors have the largest coefficient field of influence of changes in the economy, leading to produce the most significant change volume in the Cambodian economy, and as a result, to stimulate growth and create jobs. These findings reveal the importance of industrialization progress in Cambodia's economy. They align with Cambodia's Industrial Development Policy (2015-2025), which attempts to transform and modernize Cambodia's industrial structure from narrow-based and labor-intensive industries into skill-driven industries by 2025 . These findings highlight the crucial of connecting regional and global value chains and creating a productive and competitive manufacturing industry from a policy standpoint. This study suggests that Cambodian public policymakers should strengthen competitiveness, enhance domestic industries' productivities, and move toward developing a knowledge-based and technology-driven industry. In addition, investment in the transportation and communication sector should also give priority. Investment in this sector through road construction and information communication and technology (ICT), for instance, should attempt to improve distribution networks to domestic and global markets and increase market access through trade facilitation and diffusion of ICT such as the internet and mobile phones. The tourism sector is a relatively promising sector concerning the low field of influence of changes that produce small volume change in Cambodia's economy during the observed periods. However, it remains necessary to generate foreign exchange-earning through tourism exports and labor income and stimulate backward and forward linkages in the textile, other manufacturing, transportation, and communication sectors. This indicates that creating backward and forward linkages are crucial for the tourism sector to play a vital role in Cambodia's economy. These results suggest promoting, encouraging, and investing in this sector by developing domestic production linkages, especially creating domestic links between tourism with textile, other manufacturing, electricity, food and beverage, transportation and communication, and increasing the domestic industries' productivities. This strategy has significant implications for developing tourism from a low volume change to the most significant volume changes in Cambodia's economy and helps to reduce economic leakages.

\section{Appendix}

See Tables 1, 2, 3, 4 and 5 . 
Table 1 List of aggregated sectors in the study

\begin{tabular}{|c|c|}
\hline 1. Agriculture & 6. Electricity \\
\hline 1. Agriculture, hunting, forestry, and fishing & $\begin{array}{l}\text { 21. Electricity, gas, water supply, sewerage, waste, and } \\
\text { remediation service }\end{array}$ \\
\hline 2. Mining and quarrying & 7. Transportation and telecommunication \\
\hline 2. Mining and extraction of energy-producing products & 22. Transportation and storage \\
\hline $\begin{array}{l}\text { 3. Mining and quarry of non-energy producing } \\
\text { products }\end{array}$ & 23.Telecommunications \\
\hline 4. Mining support service activities & 24. Publishing, audio-visual, and broadcasting activities \\
\hline 3. Textile & 25. IT and other information services \\
\hline $\begin{array}{l}\text { 5. Textile, wearing apparel, leather, and related prod- } \\
\text { ucts }\end{array}$ & 8. Construction \\
\hline 4. Food and beverage & 26. Construction \\
\hline 6. Food products, beverages, and related products & 9. Wholesale and retail \\
\hline 5. Other manufacturing & 27. Wholesale and retail trade; repair of motor vehicles \\
\hline $\begin{array}{l}\text { 7. Wood and of products of wood and cork (except } \\
\text { furniture) }\end{array}$ & 10. Financial and insurance \\
\hline 8. Paper products and printing & 28. Financial and insurance \\
\hline 9. Coke and refined petroleum products & 11. Real estate \\
\hline 10. Chemicals and pharmaceutical products & 29. Real estate activities \\
\hline 11. Rubber and plastics products & 12. Public administration \\
\hline 12. Other non-metallic mineral products & $\begin{array}{l}\text { 30. Public administration and defense; compulsory } \\
\text { social security }\end{array}$ \\
\hline 13. Manufacture of basic metals & 13. Education \\
\hline $\begin{array}{l}\text { 14. Fabricate metal products, except machinery and } \\
\text { equipment }\end{array}$ & 31. Education \\
\hline 15. Computer, electronic and optical products & 14. Human health and social work \\
\hline 16. Electrical equipment & 32. Human health and social work \\
\hline 17. Machinery and equipment & 15. Tourism \\
\hline 18. Motor vehicles, trailers, and semi-trailers & 33. Accommodation and food services \\
\hline 19. Other transport equipment & $\begin{array}{l}\text { 34. Arts, entertainment, recreation, and other service } \\
\text { activities }\end{array}$ \\
\hline $\begin{array}{l}\text { 20. Other manufacturing; repair, and installation of } \\
\text { machinery and equipment }\end{array}$ & 35. Other business sector services \\
\hline
\end{tabular}


Table 2 Cambodia's industrial structure, 2005-2015. Source: author's calculation based on OECD's IO table, 2005-2015

\begin{tabular}{|c|c|c|c|c|c|c|c|c|c|}
\hline \multirow[t]{2}{*}{ Sectors } & \multicolumn{3}{|c|}{$\%$ gross output } & \multicolumn{3}{|c|}{$\%$ GDP } & \multicolumn{3}{|c|}{$\%$ value added } \\
\hline & 2005 & 2010 & 2015 & 2005 & 2010 & 2015 & 2005 & 2010 & 2015 \\
\hline 1. Agriculture & 30.1 & 28.1 & 28.2 & 25.6 & 26.5 & 26.1 & 30.4 & 30.5 & 28.1 \\
\hline 2. Mining and quarrying & 0.1 & 0.1 & 0.1 & 0.3 & 0.4 & 0.5 & 0.4 & 0.4 & 0.5 \\
\hline 3. Textile & 9.3 & 7.2 & 8.5 & 14.0 & 11.1 & 11.5 & 11.5 & 8.4 & 8.9 \\
\hline 4. Food and beverage & 11.7 & 11.0 & 10.6 & 8.6 & 8.1 & 8.0 & 5.9 & 6.2 & 5.1 \\
\hline 5. Other manufacturing & 9.4 & 12.7 & 13.0 & 12.5 & 14.4 & 15.4 & 9.6 & 10.8 & 10.6 \\
\hline 6. Electricity & 0.7 & 1.1 & 1.1 & 0.8 & 1.1 & 1.0 & 0.8 & 1.1 & 0.9 \\
\hline 7. Transportation and communication & 10.1 & 9.7 & 10.4 & 6.8 & 6.7 & 6.9 & 5.7 & 5.5 & 5.4 \\
\hline 8. Construction & 5.5 & 6.8 & 4.0 & 7.4 & 7.7 & 6.7 & 5.8 & 7.3 & 11.0 \\
\hline 9. Wholesale and retail & 3.8 & 4.6 & 6.0 & 7.4 & 7.7 & 8.1 & 9.3 & 9.2 & 9.3 \\
\hline 10. Financial and insurance & 1.0 & 1.3 & 1.3 & 0.9 & 1.0 & 1.1 & 1.1 & 1.3 & 1.3 \\
\hline 11. Real estates & 4.4 & 4.6 & 4.6 & 3.9 & 4.0 & 4.0 & 6.1 & 6.2 & 5.9 \\
\hline 12. Public administration & 1.6 & 1.6 & 1.7 & 1.2 & 1.2 & 1.3 & 1.6 & 1.6 & 1.6 \\
\hline 13. Education & 1.6 & 1.5 & 1.5 & 1.4 & 1.3 & 1.3 & 2.0 & 1.9 & 1.9 \\
\hline 14. Human health & 1.1 & 1.0 & 1.3 & 1.0 & 0.9 & 1.1 & 1.2 & 1.1 & 1.4 \\
\hline 15. Tourism & 9.7 & 8.8 & 8.2 & 8.2 & 7.7 & 7.0 & 8.6 & 8.5 & 8.2 \\
\hline Accommodation and food services & 4.9 & 4.4 & 4.3 & 4.0 & 3.9 & 3.5 & 4.1 & 4.2 & 4.3 \\
\hline $\begin{array}{l}\text { Arts, entertainment, recreation, and } \\
\text { other service activities }\end{array}$ & 3.9 & 3.3 & 1.8 & 3.2 & 2.8 & 1.4 & 3.3 & 3.1 & 2.4 \\
\hline Other business sector services & 0.9 & 1.1 & 2.1 & 1.0 & 1.0 & 2.1 & 1.2 & 1.3 & 1.5 \\
\hline Total & 100 & 100 & 100 & 100 & 100 & 100 & 100 & 100 & 100 \\
\hline
\end{tabular}




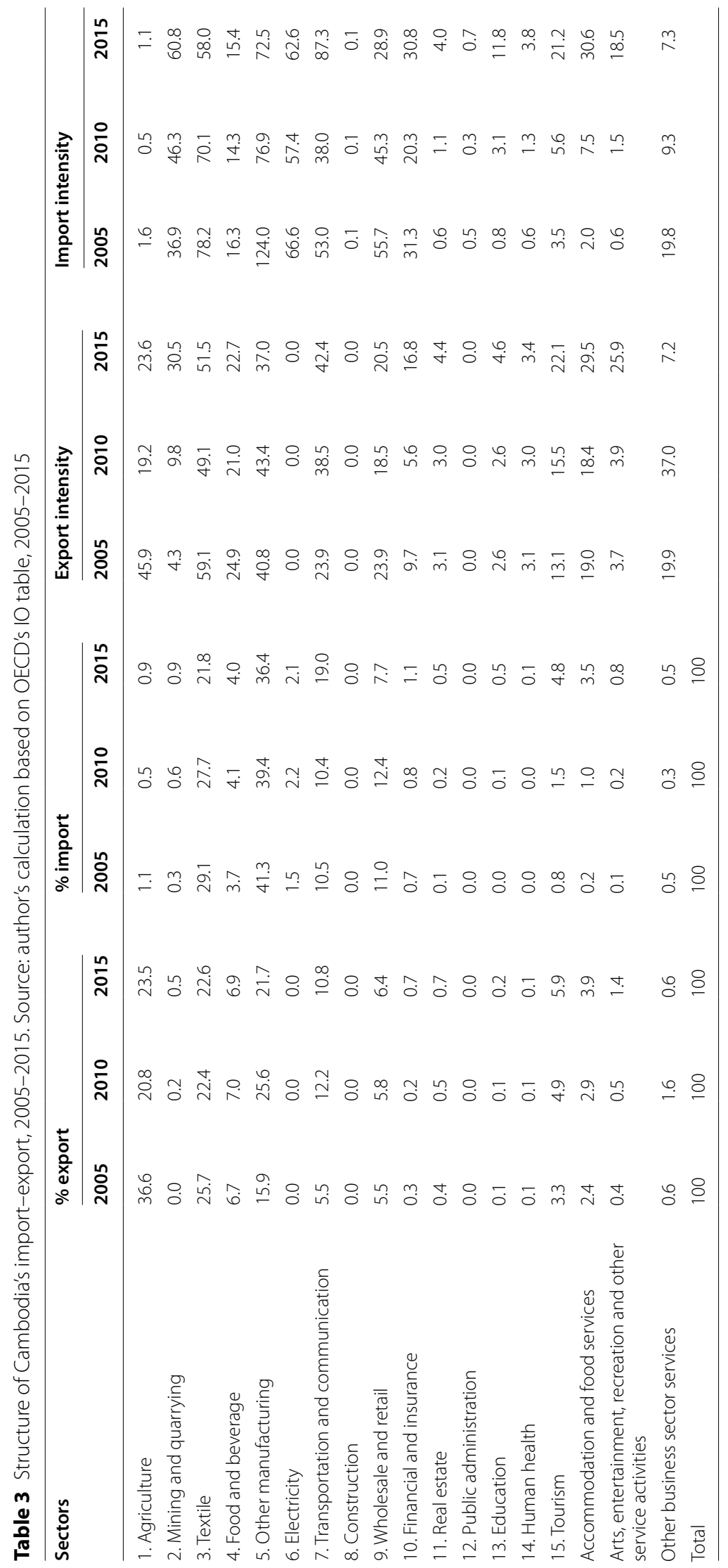


Table 4 Sector's share of labor income and its intensity, 2005-2015. Source: author's calculation based on OECD's IO table, 2005-2015

\begin{tabular}{|c|c|c|c|c|c|c|}
\hline \multirow[t]{2}{*}{ Sectors } & \multicolumn{3}{|c|}{ Labour income } & \multicolumn{3}{|c|}{ Labour income intensity } \\
\hline & 2005 & 2010 & 2015 & 2005 & 2010 & 2015 \\
\hline 1. Agriculture & 31.73 & 31.27 & 27.67 & 26.65 & 26.54 & 26.25 \\
\hline 2. Mining and quarrying & 0.39 & 0.35 & 0.35 & 25.59 & 20.20 & 19.31 \\
\hline 3. Textile & 9.36 & 5.56 & 6.85 & 14.42 & 11.23 & 14.71 \\
\hline 4. Food and beverage & 6.06 & 7.31 & 4.95 & 15.13 & 20.21 & 15.31 \\
\hline 5. Other manufacturing & 11.69 & 12.65 & 12.47 & 20.11 & 19.75 & 20.06 \\
\hline 6. Electricity & 0.66 & 0.82 & 0.71 & 17.44 & 17.24 & 17.17 \\
\hline 7. Transportation and communication & 8.79 & 8.32 & 7.78 & 27.88 & 28.02 & 28.04 \\
\hline 8. Construction & 1.81 & 5.29 & 12.47 & 5.25 & 15.38 & 46.27 \\
\hline 9. Wholesale and retail & 9.19 & 8.88 & 8.66 & 26.69 & 25.96 & 26.32 \\
\hline 10. Financial and insurance & 0.60 & 0.70 & 0.67 & 14.99 & 15.03 & 15.22 \\
\hline 11. Real estate & 3.23 & 3.19 & 2.94 & 17.64 & 17.85 & 18.18 \\
\hline 12. Public administration & 3.89 & 3.74 & 3.52 & 66.92 & 67.36 & 66.15 \\
\hline 13. Education & 3.75 & 3.52 & 3.30 & 58.29 & 60.78 & 65.26 \\
\hline 14. Human health & 0.59 & 0.54 & 0.64 & 13.22 & 13.62 & 13.78 \\
\hline 15. Tourism & 8.27 & 7.86 & 7.02 & 27.30 & 28.52 & 34.00 \\
\hline Accommodation and food services & 0.84 & 0.84 & 0.84 & 4.52 & 4.87 & 5.96 \\
\hline $\begin{array}{l}\text { Arts, entertainment, recreation, and other } \\
\text { service activities }\end{array}$ & 5.69 & 5.21 & 3.92 & 38.27 & 41.23 & 69.58 \\
\hline Other business sector services & 1.74 & 1.80 & 2.26 & 39.11 & 39.46 & 26.46 \\
\hline Total & 100 & 100 & 100 & & & \\
\hline
\end{tabular}




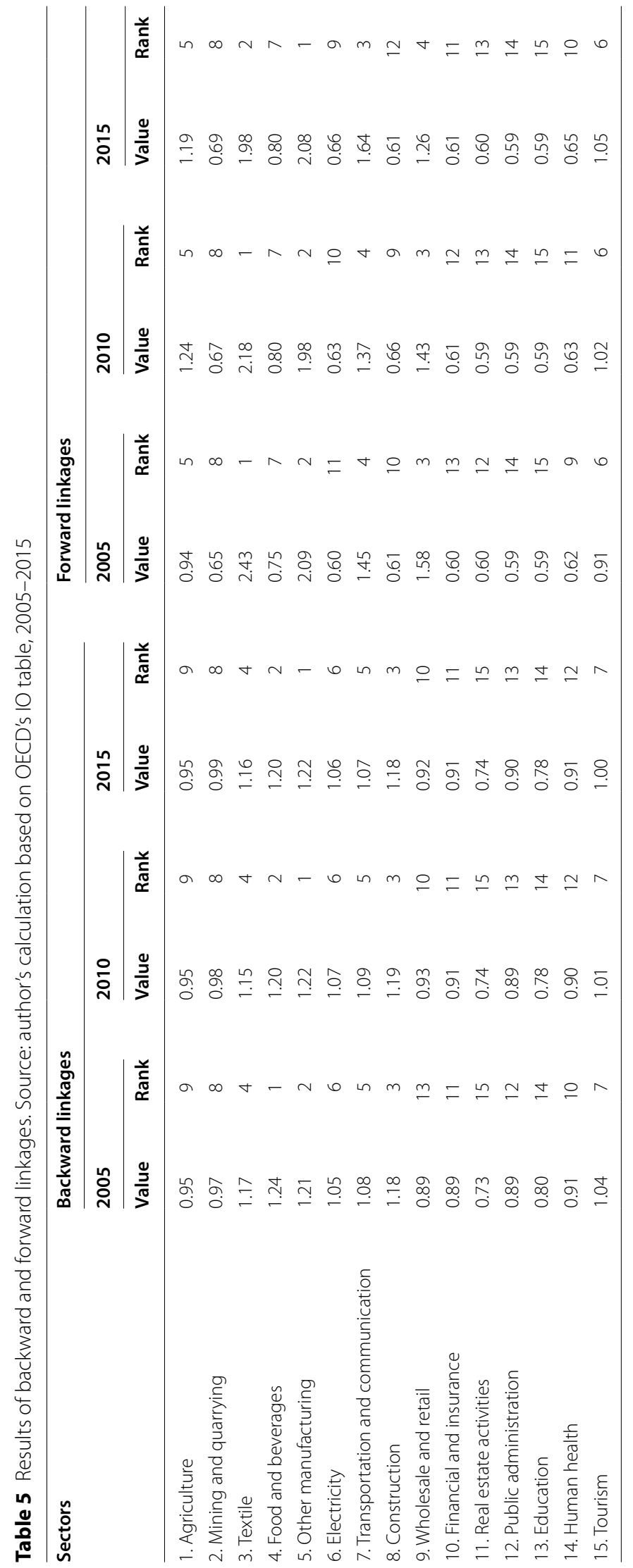




\section{Acknowledgements}

The author would like to thank Associate Professor OTCHIA Christian Samen from the Graduate School of International Development, Nagoya University, for his valuable comments and suggestions on the methodology. I also thank Professor Shigeru T. Otsubo, Professor Tetsuo Umemura, Dr. Pradeep Panthi, and the other two anonymous reviewers for their thoughtful comments and advice on this work.

\section{Authors' contributions}

The author read and approved the final manuscript.

\section{Funding}

Not applicable.

\section{Availability of data and materials}

This study uses the input-output tables obtained from the IO OECD database. The tables are available to download at https://stats.oecd.org/Index.aspx?DataSetCode=IOTSI4_2018.

\section{Declarations}

\section{Competing interests}

The author declares no competing interests.

Received: 28 February 2020 Revised: 1 September 2021 Accepted: 1 September 2021

Published online: 15 September 2021

\section{References}

ADB (2012) Supply and use tables for selected economics in Asia and the Pacific. Asia Development Bank

Akkemik K (2012) Assessing the importance of international tourism for the Turkish economy: a social accounting matrix analysis. Tour Manag 33(4):790-801

Antara M, Sumarniasih M (2017) Role of tourism in the economy of Bali and Indonesia. J Tour Hosp Manag 5(2):34-44. https://doi.org/10.15640/jthm.v5n2a4

Archer B, Fletcher J (1996) The economic impact of tourism in Seychelles. Ann Tour Res 23(1):32-47

Asian Development Bank (2009) Strategic environmental assessment of the tourism sector in Cambodia. In: Strengthening sustainable tourism. Available via Dialog. http://www.mseoc.org/uploads/resources/30/attachment/Strengthen ing\%20Sustainable\%20Tourism\%20\%20SEA\%20of\%20the\%20Tourism\%20Sector\%20in\%20Cambodia.pdf. Accessed 21 Jan 2020

Asian Development Bank (2019) Key indicators for Asia and the Pacific 2019. https://data.adb.org/dataset/Cambodia-keyindicators. Accessed 14 Jan 2020

Asuyama Y, Neou S (2012) How has the Cambodian garment industry evolved? In: Fukunishi (ed) Dynamics of the garment industry in low-income countries: experience of Asia and Africa, IDE-JETERO

Atan S, Arslanturk Y (2012) Tourism and economic growth nexus: an input-output analysis in Turkey. Procedia Soc Behav Sci 62:952-956

Beynon M, Jones C, Munday M (2009) The embeddedness of tourism-related activity: a regional analysis of sectoral linkages. Urban Stud 46(10):2123-2141

Cai J, Leung P, Mak J (2006) Tourism's forward and backward linkages. J Travel Res 45(1):36-52

Celia G (1984) The input-output measurement of interindustry linkages. Oxf Bull Econ Stat 46(1):73-84

Chaivichayachat B (2017) Inter-industry linkage of tourism-related sectors in Thailand: past, present, and future. Information 20(10):7191-7198

Chenery H, Watanabe T (1958) International comparisons of the structure of production. Econometrica 26(4):487-521

Chheang V (2009) State and tourism planning: a case study of Cambodia. Tourismos 4(1):63-82

Chhuor S (2017) Potential roles of the export orientation of Cambodia's agriculture and agro-industry: an application of CGE analysis. J Econ Struct. https://doi.org/10.1186/s40008-017-0087-6

Defourny J, Thorbecke E (1984) Structural path analysis and multiplier decomposition within a social accounting matrix framework. Econ J 94(373):111-136

Dwyer L, Forsyth P, Spurr R (2003) Inter-industry effects of tourism growth: implications for destination managers. Tour Econ 9(2):117-132

Ferrari G, Mondéjar J, Secondi L (2018) Tourists' expenditure in Tuscany and its impact on the regional economic system. J Clean Prod 171:1437-1446

Fletcher JE (1989) Input-output analysis and tourism impact studies. Ann Tour Res 16:514-529

Freeman D, Sultan E (1997) The economic impact of tourism in Israel: a multi-regional input-output analysis. Tour Econ 3(4):341-359

Gabriel L, Ribeiro L (2019) Economic growth and manufacturing: an analysis using panel VAR and intersectoral linkages. Struct Chang Econ Dyn 49:43-61

Grosso G, Lesher M, Pinali E (2007) Service trade liberalization and tourism development. OECD Trade Policy Papers, No. 57. https://doi.org/10.1787/18166873

Henry E, Deane B (1997) The contribution of tourism to the economy of Ireland in 1990 and 1995. Tour Manag 18(8):535-553

Hirschman A (1958) The strategy of economic development. Yale University Press, New Haven 
Hor C, Thaiprasert N (2014) Analysis of international tourism demand for Cambodia. In: Huynh VN, Kreinovich V, Sriboonchitta S, Suriya K (eds) Econometrics of risk. Springer, Cham

Jones C, Munday M (2010) Tourism satellite accounts for regions? A review of development issues and an alternative. Econ Syst Res 22(4):341-358

Kaynak E, Kara A (2012) Assessing tourism market potential in a dynamic emerging economy: theoretical and empirical insights from Cambodia. Asia Pacific J Mark Logist 24(2):199-221

Khanal B, Gan C, Becken S (2014) Tourism inter-industry linkages in the Lao PDR economy: an input-output analysis. Tour Econ 20(1):171-194

Kim H, Kim B (2015) Economic impacts of the hotel industry: an input-output analysis. Tour Rev 70(2):132-149

Kobayashi S, Tanji H, Saito K, Huang W, Tada M (2009) Industrial structure of Cambodia and the role of agriculture and fishery in its development. Jpn Agric Res Q 43(4):309-316. https://doi.org/10.6090/jarq.43.309

Kronenberg K, Fuchs M, Lexhagen M (2018) A multi-period perspective on tourism's economic contribution-a regional input-output analysis for Sweden. Tour Rev 73(1):94-110

Kweka J, Morrissey O, Blake A (2003) The economic potential of tourism in Tanzania. J Int Dev 15(3):335-351

Madsen B, Zhang J (2010) Towards a new framework for accounting and modeling the regional and local impacts of tourism. Econ Syst Res 22(4):313-340

Mazumder M, Ahmed E, Murad M, Alamin A (2011) Identifying economically potential inbound markets for the Malaysian tourism industry. J Vacat Mark 17(1):31-49. https://doi.org/10.1177/1356766710391133

Miller R, Blair P (2009) Input-output analysis: foundations and extensions, 2nd edn. Cambridge University Press, New York

MOT (2012) Tourism development strategic plan 2012-2020. Ministry of Tourism 53(9):1-53

MOT (2019) Tourism annual statistics report. Ministry of Tourism, Phnom Penh, Cambodia

Muchapondwa E, Stage J (2013) The economic impacts of tourism in Botswana, Namibia, and South Africa: is poverty subsiding? Nat Resour Forum 37(2):80-89

Munjal P (2013) Measuring the economic impact of the tourism industry in India using the Tourism Satellite Account and input-output analysis. Tour Econ 19(6):1345-1359

Oosterhaven J, Fan T (2006) Impact of international tourism on the Chinese economy. Int J Tour Res 8(5):347-354

Otchia C (2013) How could industrial structure guide the choice of a development strategy? A field of influence analysis for the Democratic Republic of Congo. Int J Econ Policy Stud 8(1):89-112

Otchia C (2019) Structural change and premature deindustrialization in the Democratic Republic of Congo in 1970-2013: an input-output perspective. In: Abstracts of the 27th input-output association conference, Glasgow, Scotland, 27 June 2019

Pambudi D, McCaughey N, Smyth R (2009) Computable general equilibrium estimates of the impact of the Bali bombing on the Indonesian economy. Tour Manag 30(2):232-239

Pratt S (2011) Economic linkages and impacts across the talc. Ann Tour Res 38(2):630-650

Pratt S, Suntikul W, Dorji U (2018) Economic sustainability? Examining the linkages and leakages between agriculture and hotels in Bhutan. Int J Tour Res 20(5):626-636

Rasmussen P (1956) Studies in inter-sectorial relations. Amsterdam, North-Holland

ROG (2018) Rectangular strategy for growth, employment, equity, and efficiency: building the foundation toward realizing the Cambodia vision 2050 phase IV. Phnom Penh, Cambodia

Schultz S (1977) Approaches to identifying key sectors empirically utilizing input-output analysis. J Dev Stud 14(1):77-96

Smeral E (2015) Measuring the economic impact of tourism: the case of lower and upper Austria. Tour Rev 70(4):289-297

Sonis M, Hewings G, Sulistyowati S (1997) Block structural path analysis: applications to structural changes in the Indonesian economy. Econ Syst Res 9(3):265-280

Sonis M, Hewings JD, Guo J (2000) A new image of classifical key sector analysis: minimum information decomposition of the Leontief inverse. Econ Syst Res 12(3):401-432

Teigeiro L, Diaz B (2014) Estimation of multipliers for the activity of hotels and restaurants. Tour Manag 40:27-34

Temurshoev U (2010) Identifying optimal sector groupings with the hypothetical extraction method. J Reg Sci 50(4):872-890

Tohmo T (2018) The economic impact of tourism in Central Finland: a regional input-output study. Tour Rev 73(4):521-547

UNWTO (2018) Tourism and sustainable development goals-good practices in the Americas. Madrid, Spain

Vora-Sittha P (2016) Economic impact of tourism accommodation: Thailand. Asian Soc Sci 12(7):222-230

World Development Indicators (2021) https://datacatalog.worldbank.org/dataset/world-development-indicator. Accessed 1 Mar 2021

WTTC (2019) World travel and tourism economic impact 2019. https://www.wttc.org/-/media/files/reports/economicimpact-research/regions-2019/world2019.pdf. Accessed 14 Jan 2020

Yamagata T (2006) The garment industry in Cambodia: its role in poverty reduction through export-oriented development. Discussion Paper No. 62, Institute of Developing Economies

Yousif M, Bakr A (2017) Tourism development effect on Saudi economic diversification. J Gulf Econ 1(1):1-20

Zha J, Shao Y, Li Z (2019) Linkage analysis of tourism-related sectors in China: an assessment based on network analysis technique. Int J Tour Res 21(4):531-543

\section{Publisher's Note}

Springer Nature remains neutral with regard to jurisdictional claims in published maps and institutional affiliations. 